\title{
HLA-DQA1 wt Allele
}

National Cancer Institute

\section{Source}

National Cancer Institute. HLA-DQA1 wt Allele. NCI Thesaurus. Code C71266.

Human HLA-DQA1 wild-type allele is located in the vicinity of 6p21.3 and is approximately $6 \mathrm{~kb}$ in length. This allele, which encodes HLA class II histocompatibility antigen, DQ alpha chain protein, plays a role in antigen presentation and the regulation of the immune response. The gene is polymorphic and typing is often performed to determine histocompatibility for hematopoietic stem cell transplantation. 